\title{
The Effects of Ebola Virus on the Economy of West Africa through the Trade Channel
}

\author{
Olusegun Adegun.
}

\begin{abstract}
This study investigates the impact of Ebola on West African Economies through the trade channel, articles from relevant journals and trade data of West African countries were gathered from National Bureau of Statistics, and other relevant organizations', previous literatures on the relationship between health, trade and growth were also discussed. It was discovered that Ebola virus will affect the GDPs of West African economies of Liberia, Sierra Leone and Guinea more than Nigeria
\end{abstract}

\section{Introduction:}

Ebola virus first broke out in Zaire and Sudan in 1976. Mortality rates were $88 \%$ in Zaire and $66 \%$ in Sudan, with 500 cases. In one small village in Zaire, 274 out of 300 people infected in an outbreak died. This disease resurfaced in 1995 according to the Zairian health ministry affecting medical professionals. 170 had died as of May $11^{\text {th }} 1995$ in response to people fleeing Kikwit and possibly spreading the virus. The government of Zaire attempted to cordon off the city to keep inhabitants from spreading the disease across the countryside and possibly even into the slums of Kinshasa, Zaire's capital. Kikwit was put under quarantine. It was unable at that period to contain the spread of the virus even with the support of international medical experts from Belgium, France, and South Africa. Poor health infrastructure, inadequate proactive measures can be attributed to the failure of the government during that time to contain the spread. (Rupavate S, 2014).

In recent times, the Ebola virus was reported first in Guinea in March 2014. Now the virus has spread to other West African nations like Liberia, Sierra Leone, Nigeria, and Senegal. The major scare of this deadly virus is the number of lives that have already been claimed ranging from 42-66\%. (World Health Organization, 2014). As of September $10^{\text {th }} 2014$, a total of 2,281 deaths had been recorded out of 4,614 suspected or confirmed cases (World Bank, 2014). One immediate reaction by government authorities was to regulate movement through partial or total closure of borders. On July $27^{\text {th }} 2014$, the Liberian president announced her country's decision to close its borders expect for few crossing points, like the international airports. Senegal closed its borders with Guinea and Cameroon has also closed its borders with Nigeria. Sierra Leone has declared a state of emergency, while other West African nations like Nigeria are subjecting passengers at the airports to screening to ascertain their health status. As a result of the epidemic many events such as conferences, seminars and workshops scheduled to take place on the continent are being cancelled or postponed. Airlines are also cancelling flights to affected nations. For example; British Airways, Emirates and Asky airlines have cancelled flights to Sierra Leone and Liberia. Aside this, international businesses are already recalling their employees from these countries. In Liberia, Caterpillar Inc has evacuated a handful of employees and Canadian Overseas Petroleum Ltd has suspended a drilling project, Dangote Group of Companies has pulled out its employees, and the recent lockdown in Sierra Leone is also a potential threat to national productivity and growth. The above mentioned outcomes of the deadly disease could have severe consequences on economic growth in West African nations if it persists. Previous studies on the relationship between health and economic growth have alluded to the fact that virus outbreaks could impact negatively on economic growth. Arndt and Lewis (2000) and (2011) used a multi sector computable general equilibrium model to examine the impact of HIV / AIDS on South African economic growth, and predicted that by 2010 annual (G.D.P.) in South Africa would be 17\% smaller in the presence of AIDS

(Over, 1992) performed a cross country regression study across 30 Sub-Saharan African countries and suggest that AIDS could lead to a $0.56 \%$ to $1.08 \%$ drop in the level of annual GDP growth between 1990 and 2025. (Sackey and Rarpala, 2000) projected Lesotho's GDP growth in 2010 would drop from $4.0 \%$ without AIDS to $2.4 \%$ with the disease, and in 2015 , drop from $4.0 \%$ to $1.3 \%$. (Alemu et al, 2005) using panel data for over 100 countries examined the effect of HIV on factor productivity growth and concluded that factor productivity growth fell by $23 \%$ in Lesotho and in South Africa it fell by $15 \%$. (Gall up and Sachs, 2001) conducted a study on the economic burden of malaria using cross- country regressions from 1965-1990, and discovered that countries with intensive malaria grew $1.3 \%$ less per year and a $10 \%$ reduction in malaria was associated with $0.3 \%$ higher growth. (Bloom et al, 2004) argued that East Asian growth miracle was no miracle at all: rather it represents compelling evidence for a process in which health improvements played a leading role 
in economic growth. These suggest that national health epidemics could have significant negative impact on economic activities and productivity, especially GDP growth.

In terms of the relationship between trade and growth, (Sach and Warner, 1995) suggested that openness to international market, place of goods; foreign investments and technology are crucial elements of any pro-growth reform package. (Gossel and Biekpe, 2013) argued that economic growth in South Africa is driven primarily by trade and fixed investments. (Rodrick et al, 2002) mentioned that positive long run effects of trade on economic growth will arise only when trade openness is combined with appropriate institutional frameworks and policies that encourage investment, allow effective conflict resolution, and promote human capital accumulation.

With the prospects of larger economic boom in the African continent, as a result of its current rapid economic growth, one could expect the Ebola virus to stall the growth of West Africa due to outcomes from previous studies regarding 'Health and Growth' vis a vis 'Trade and growth'. One major aspect where this crisis is going to affect is trade because of the closure of the borders and cancellation of flight movements. Therefore, this study takes a look at the impact of the Ebola virus on the economies of West African nations and explores the effect through trade, while assessing other channels the virus would impact on West African economies.

To arrive at the above mentioned objective, articles from relevant journals and trade data of West African countries will be gathered from National Bureau of Statistics, and other relevant organizations' websites to understand the current level of trade relations amongst these countries. Data on the Ebola virus will be collected from websites like: World Health Organization (W.H.O) ministry of health etc. Newspaper articles will also be reviewed. This paper is divided into following sections; Introduction, overview of the ECOWAS economies to understand their current state of growth with particular attention on trade in the Ebola affected nations, review of intra ECOWAS trade, impact of Ebola on trade, other channels of impact (FDI, tourism) and conclusion.

\section{Overview Of West African Economies}

The aim of this section is to describe the state of West African economies, focusing on their GDPS, the major drivers of growth, and the level of their economic fragility.

West Africa is steadily progressing economically and socially and remains the fastest growing region on the continent. Growth accelerated from 3\% in 2011 to $6.4 \%$ in 2013 and is projected to reach up to $7.1 \%$ in 2014 and 2015, compared to $4.8 \%$ and $5.7 \%$ for the continent as a whole. This growth rate is propelled by developments in agriculture, manufacturing, and services sector respectively. The average external current account balance for the region is projected to continue to be positive in 2014 at 2.3\% of GDP. (Africa Economic Outlook, 2014). However, many of the countries are still heavily dependent on commodity exports, making them vulnerable to price swings and fluctuations in external demand. (AFDB West Africa Monitor Quarterly, 2014).In light of the above, the West African region can be said to be achieving steady progress but what is the current economic status of states in the region?

\subsection{Current Economic Profile of West African States}

Nigerian newly rebased GDP from 1990-2000 at current market prices was estimated to be around USD 510 billion by the end of 2013. This good performance was driven largely by the non-oil sector, although its contribution to export earnings has been very small. While between 2011 and 2013 the non -oil sector annual growth averaged $7.1 \%$ with a peak of $8.3 \%$ in 2012, significantly improved by $5.2 \%$ in 2013 . Despite its poor performance, the oil sector contributed an estimated $96 \%$ to total export earnings in 2013.The real GDP growth rate closed in 2013 at an estimated $7.4 \%$ up from $6.7 \%$ in 2012. This performance was buoyed mainly by strong performance in the non-oil sector: agriculture, construction, hotel and restaurants. The prospect for economic growth is projected at more than 6\% in 2014 and 2015. Merchandise exports and imports continued to be dominated by the oil sector in 2013. The share of oil exports remained at an average of $96.7 \%$ of total exports. The share of refined oil product imports has been on a steady increase from $26.7 \%$ in 2008 to $35.8 \%$ in 2012, settled around $30 \%$ in 2013. The import share of total trade declined slightly to an estimated $23.2 \%$ in 2013 from 25.2\% in 2012. (African Economic Outlook, 2014)

Liberia's economy grew at $8.1 \%$ in 2013 , led by increasing iron ore exports, construction, and a robust service sector. Real GDP is projected to expand by $6.8 \%$ in 2014 and $8.2 \%$ in 2015. Increasing iron ore production and FDI continues to support this growth. Growth in agriculture, fisheries and forestry sector was limited in 2013 due to weak rubber output, a drop in timber exports and stagnant agricultural production. The sector comprises about one third of GDP. Rubber production declined by $13 \%$, due to lower international prices. Industrial and manufacturing sector expanded substantially in 2013, due to a continuing increase in iron ore production. The sector represents about $25 \%$ of GDP, but only employs about $8 \%$ of the labor force. The service sector experienced around 9\% growth in 2013 and contributes around 44\% of GDP. Main activities include: 
Trade and hotels, government services, real estate, construction, transport and communication. Export growth continued in 2013 due to increased iron ore production, which became Liberia's leading export, ahead of rubber. The trade balance widened, with strong imports. These imports contribute to a large current account deficit estimated at $48 \%$ of GDP in 2013. (African Economic Outlook, 2014)

Sierra Leone has recently shown strong macroeconomic improvements including an accelerated economic growth, A change in the composition of growth drivers from activities in agriculture, construction, manufacturing and services sector to an iron ore led growth has characterized developments in recent years. Prior to this, growth in agriculture, construction, manufacturing and service sector averaged 5.7\% per annum during 2010-2012. Total exports receipts increased by $56.9 \%$ from USD 1.065 .47 million in 2012, showing improvements in earnings from mineral exports, namely diamonds rutile and iron ore together with other exports. The trade balance improved from $-55 \%$ of GDP in 2011 to $-24.6 \%$ in 2013 and is projected to stabilize around that through 2015. (African Economic Outlook, 2014)

Guinea's economic growth was estimated at $2.0 \%$ in 2013 (down from $3.9 \%$ in 2012) due to political unrest and a drop in mining investment. Growth should increase to $4.2 \%$ in 2014 , driven by agriculture, and construction. Mining dominates the economy, mainly bauxite, gold and diamonds. Exports continued to drop in 2013, to $23.6 \%$ of GDP (from $26.8 \%$ in 2012 and $31.2 \%$ in 2010), and should be $20.1 \%$ in 2014. Imports fell slightly to $41 \%$ of GDP at the end of 2013 (from $45.1 \%$ in 2012 and $29.4 \%$ in 2010). The current account has been in deficit since 2010, at 20.2\% of GDP in 2013 (down from 33.9\% in 2012 and $11.9 \%$ in 2010) an improvement should continue in 2014 because of fewer imports and revived mining exports. The overall balance of payment improved to 2.2\% of GDP at the end of 2013 and is projected at 2.4\% in 2014.(African Economic Outlook, 2014). From the afore mentioned facts above, one can say that the West African states affected by Ebola virus are progressive economies based on their GDP figures, aside from Guinea that is gradually recovering from political unrest and its GDP is projected to improve in 2014 . A large portion of these countries GDP growth can be attributed to exports from agriculture, mining, and oil sector.

In summary, it can be inferred from the above facts that West African economies have performed well based on their GDP growth within the past year, expect for countries like Mali, Guinea, and Guinea Bissau that are gradually recovering from political unrest. These countries' economies are export driven (Agriculture, mining, and oil production) and it makes up a large portion of their GDP, all countries most hit by the virus are fragile states coming out of long periods of conflicts. Therefore the scourge of the Ebola virus, could reverse this growth rates through loss of productivity, and increased poverty.

\section{Review Of Intra Ecowas Trade}

In the previous section, it was concluded that West African economies are growing, and these growth rates can be reversed by the Ebola virus. In this section, a review of trade relations amongst West African countries will be examined with particular emphasis on Ebola affected states, to discover the volume of trade amongst them.

\subsection{Background: Regional Trade in ECOWAS}

The ECOWAS region includes 15 countries in West Africa. It can be subdivided in two groups: The eight Union Economique et Montaire Ouest Africaine (UEMOA) members (Benin, Burkina Faso, Cote d' Ivoire, Guinea Bissau, Mali Niger, Senegal and Togo), who adopted the CFA franc as a common currency, and non-UEMOA members Cape Verde, Ghana, Guinea, The Gambia, Nigeria, Liberia and Sierra Leone. (Erik von Uexkull, 2012).

ECOWAS was established in 1975 as a free trade area. In 2000, UEMOA also became a custom union, which was eventually extended to cover all of ECOWAS. However, the actual implementation of both internal liberalization and the common external tariff has been very slow and many member countries in practice still do not fully comply with their obligations. A number of regional institutions were created to support and govern the regional integration process, including the ECOWAS commission, Community Parliament, Court of Justice, and the ECOWAS bank for investment and development. Beyond trade policy, additional integration steps were taken in a number of areas. For example the cross-border initiative program was launched to support projects in areas such as security, agriculture and trade.(Erik von Uexkull, 2012).

ECOWAS members are a rather heterogeneous group of countries. Nigeria is by far the largest member both in terms of its population and economic weight. Per capita GDP in the region ranges from USD 396- USD 3650. With the exception of Cape Verde, Nigeria, Ghana and Cote d' Ivoire, all ECOWAS members are classified as least developed countries. In terms of its economic structure, only a few member countries have developed sizeable manufacturing industries, while most other depend primarily on agriculture, services and in some cases oil and mineral extraction. Mali, Niger and Burkina Faso are landlocked, while other member countries have access to the sea. Despite the above political efforts; the share of regional trade in ECOWAS has remained constant at a rather low level over the past two decades. (Between 10\% and 15\% of total exports go to 
regional markets with some fluctuations, but no clear trend) Nigeria dominates the region's total exports; these consist mainly of oil and are to large extent directed to the global market. (Erik von Uexkull, 2012). Below is a table that shows the breakdown of Export share by region for ECOWAS countries.

Figure 1: Export share of trade by region for ECOWAS countries. -ECOWAS $=$ Other SSA $\approx B R I C \quad \square$ High income OECD $\quad$ RoW

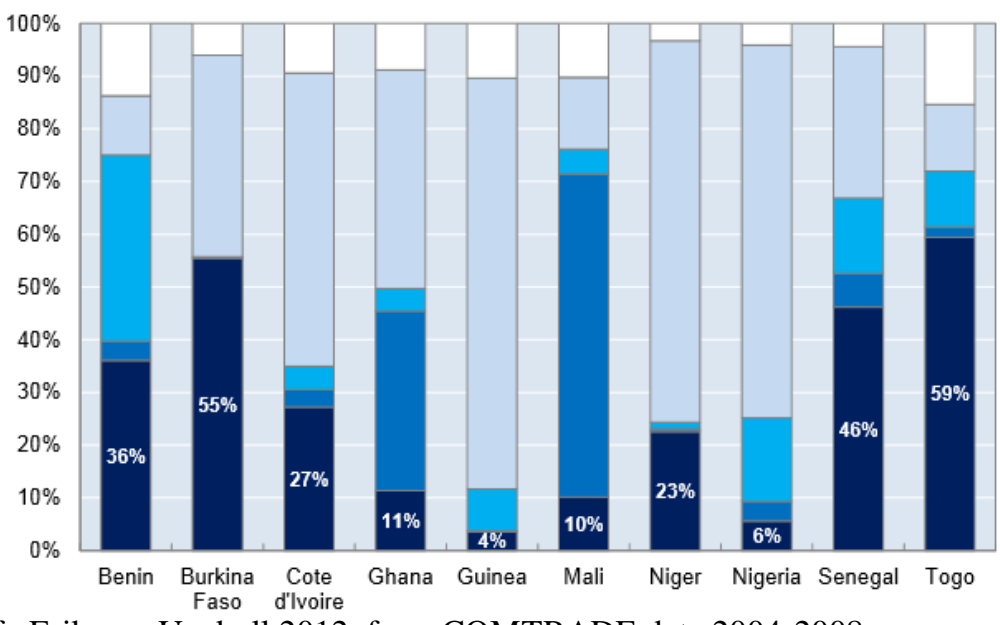

Source: Calculation of Erik von Uexkull 2012, from COMTRADE data 2004-2008

The above figures shows that the trade volumes of Guinea and Nigeria with other West African states are in single digits compared to other countries like Togo, Senegal and Burkina Faso. The figure generally shows that the volumes of trade between ECOWAS countries are less compared with trade transactions with other continents. This implies that Ebola will impact more on trade between ECOWAS and countries from other continents.

\subsection{Trade In West Africa. (Nigeria, Sierra Leone, Liberia and Guinea)}

Nigeria's trade volume with ECOWAS and other countries (United States of America, United Kingdom and China in terms of exports from the year 2011-2013 has not been stable; there have been variations' below is a table that describes the current trend of trade with West African nations and countries from other continents.

Table1: Value of Nigeria's Exports to (ECOWAS, United Kingdom, United States and China)

\begin{tabular}{|l|l|l|l|}
\hline Countries & 2011 & 2012 & 2013 \\
\hline ECOWAS & $\$ 553,181.00$ & $\$ 869,569.00$ & $\$ 396,712.80$ \\
\hline U. S.A. & $\$ 4,381,268.20$ & $\$ 3,969,537.90$ & $\$ 855,334.90$ \\
\hline U.K. & $\$ 1,210,609.40$ & $\$ 1,480,800.30$ & $\$ 406,073.70$ \\
\hline CHINA & $\$ 392,574.90$ & $\$ 933,306.50$ & $\$ 75,283.60$ \\
\hline
\end{tabular}

Source: National Bureau of Statistics

\section{Nigeria's Value of Exports}

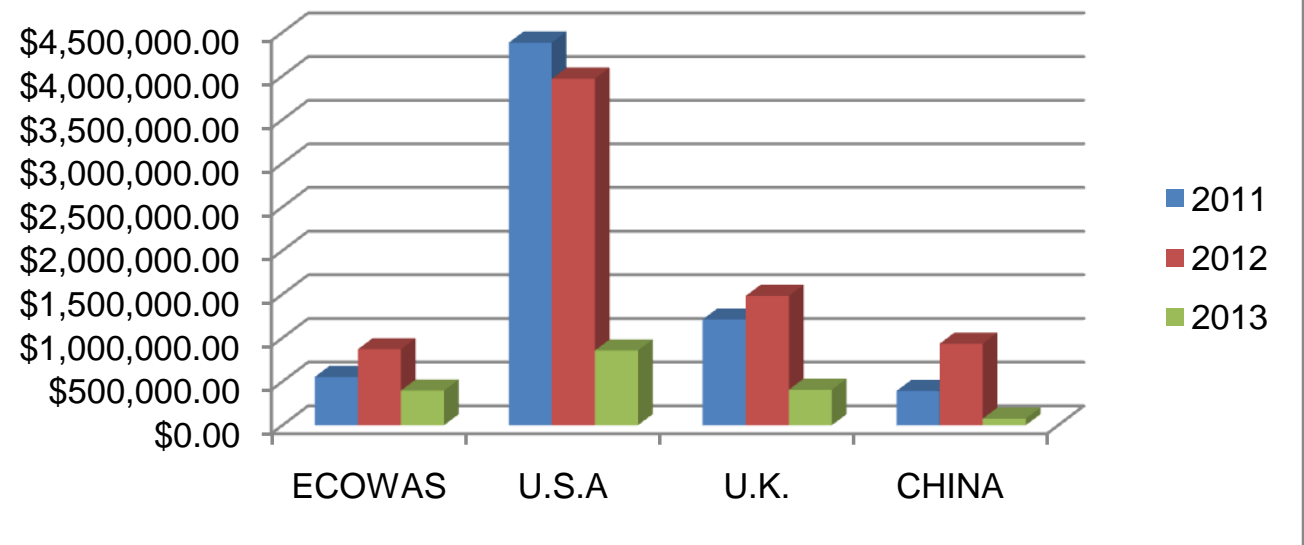

Source: National Bureau of Statistics. 
Value: (Millions)

In the year 2011, the value of Nigeria's exports to the United States was $\$ 4,381,268.20$, while that of the United Kingdom was $\$ 1,210,609.40$ followed by ECOWAS at $\$ 553,181.00$ while that of China was the least $\$ 392,574.90$. In 2012 the value of exports to United States decreased to $\$ 3,969,537.90$ while that of ECOWAS increased to $\$ 869,569.00$ and that of United Kingdom and China increased to $\$ 1,480,800.30$ and $\$ 933,306.50$ respectively. In 2013 the slump in the value of Nigeria's export to the United States continued at $\$ 855,334.90$ and that of ECOWAS also fell to $\$ 396,712.80$ for the United Kingdom and China the value decreased to $\$ 406,073.70$ and $\$ 75,283.60$ respectively. What can be deduced from the above data is that, the value of exports to the United States declined continuously for three years due to disruptions in production owing to cases of oil theft, shut down of facilities, vandalization in the oil producing areas and America's cut down on oil purchase from Nigeria. For ECOWAS , the reason for the decline in 2013 is attributed to a wide spread infrastructural deficit: delays in obtaining necessary connections to electricity, telecommunications, high volumes and range of non-tariff barriers, the number of check points erected by law enforcement agents along the highways connecting West African countries range from seven per 100 kilometers between Lagos and Abidjan and two per kilometers between Accra and Ouagadougou, differing standards and certifications measures are also argued to be contributory factors .(Louis et al, 2010). As regards the United Kingdom the decline in value of exports can be attributed to strict Europe union law which led to a ban on products from Africa that was discovered to be sub-standard. Although the negative change in value of export to China is strange, no clear evidence has been given for the decline, but one can assume certain factors responsible for the slump which includes: Oil theft, ageing of Nigeria's oil fields which are affecting the rate of production, and competition from other African countries like Angola. The key point is that Nigeria's exports more to foreign countries than states within its region.

Table 2: Nigeria's value of Imports (ECOWAS, United Kingdom, China and United States)

\begin{tabular}{|l|l|l|l|}
\hline Countries & 2011 & 2012 & 2013 \\
\hline ECOWAS & $\$ 129,526.60$ & $\$ 33,828.70$ & $\$ 65,065.50$ \\
\hline U.S.A. & $\$ 1,781,000.90$ & $\$ 766,284.10$ & $\$ 238,939.90$ \\
\hline U.K. & $\$ 262,836.10$ & $\$ 370,157.70$ & $\$ 188,066.70$ \\
\hline CHINA & $\$ 1,460,988.00$ & $\$ 1,209,780.10$ & $\$ 723,481.20$ \\
\hline
\end{tabular}

\section{Nigeria's Value of Imports}

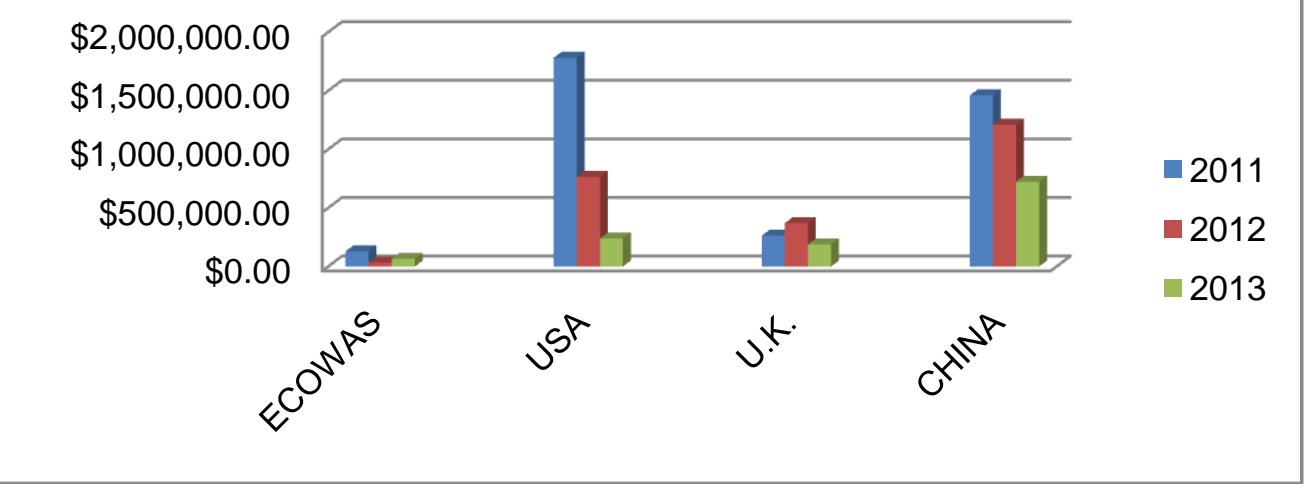

Source: National Bureau of Statistics.

The value of imports from ECOWAS between 2011-2013 is less than the export values; the reason given for this decline is the level of high tariffs imposed on goods from ECOWAS countries. Regarding imports from the United States the decline can be as a result of United States reduction of Nigeria's imports. In a nut shell, after comparing export and imports value across countries it can be said that Nigeria's exports and imports less goods from ECOWAS countries. Therefore, the Ebola outbreak in the state (Nigeria) will have a negative impact on her economy largely through trade with other continents. Will the case of Liberia, Sierra Leone, and Guinea be similar to that of Nigeria?

From the food security perspective, the most noteworthy cross-border trade flows are imported rice from Cote-d'Ivoire to south eastern Liberia, and palm oil from both Liberia and Sierra Leone to Guinea. Sierra Leone is the principal gari source for markets in Conakry and Monrovia. Sierra Leone also exports substantial quantities of local rice to Guinea. In other words Guinea demands local rice and gari (mainly from Sierra 
Leone) and palm oil from both (Sierra Leone and Liberia) the drivers of cross border trade flows. (WFP report, 2010)

Imported rice that comes from Cote d'Ivoire is mostly traded within the national borders of Sierra Leone and Liberia. This food substance is transported through the main port of entry in Monrovia before it arrives in Sierra Leone. Western Sierra Leone then routinely exports parboiled rice to nearby Conakry. It is estimated that some 360 tons of local parboiled rice entered Guinea every month during the last quarter of 2009. Palm oil trade crosses borders from Liberia and Sierra Leone to Gueckedou market in Guinea. It is estimated that whole sale palm oil market in Liberia handles 90,000 liters of palm oil every week during the marketing season and $60 \%$ is exported to Guinea. In Sierra Leone, it is estimated that about 30,000 liters of palm oil is handled in the international market and two-thirds is traded in Conakry. This palm oil is also re-exported from Guinea to neighboring Senegal and Gambia. Gari surpluses from coastal Sierra Leone are exported to Guinea and to Liberia. Quantities of groundnuts are exported from Guinea to Sierra Leone. Some 400 tons of shelled groundnuts enters Sierra Leone every week all year round. Liberia also imports this product from Guinea. In terms of livestock demand for meat, it is largely satisfied by Guinea to Sierra Leone and Liberia. (WFP report, 2010)

From the above analysis, it has been established that Nigeria's trade with ECOWAS countries is negligible but trade between Liberia, Sierra Leone and Guinea in terms of food production is significant. Therefore, one can argue that the impact of the Ebola virus on West African economies through the trade channel will impact more on Guinea, Liberia and Sierra Leone than Nigeria. However, how are these impacts going to be felt? This will be discussed in the subsequent section

\section{Impact of Ebola on West African Economies through trade:}

Ebola virus has resulted in movement restrictions and high level mortality rate of over 2,000 people, which has affected trade in West Africa. The major individuals affected in the region are those employed in the agricultural and mining industry. These sectors employ a large amount of West Africa's populace, e.g. In Sierra Leone, the rate of agro workers is about $66 \%$, Liberia the figure is more than one half of the population, Guinea (80\%), while in Nigeria (70\%). (African Economic Outlook, 2014). Therefore, discussions in this section will focus on Ebola virus impact on agriculture, mining industry and other sectors of the economy.

\subsection{Impact on Agricultural sector:}

The agriculture sector accounts for about one-quarter of Liberia's GDP, but nearly half of the total employed workforce and three quarters of the rural workforce is engaged in the sector. (World Bank report, 2014). Exports and production have been severely affected by the virus outbreak. Production and shipment of rubber the major agricultural export for Liberia -have been disrupted by both the reduced mobility of workers and the difficulty of getting products to the ports due to quarantine zone. Rubber exports which were initially expected to be about U\$148million in 2014 are estimated to drop 20percent.The world largest producers of palm oil, Sime Darby, have slowed down production due to evacuation of managerial and supervisory personnel, Construction of US\$ 10million modern palm oil mill for which construction started in July 2014 has been put on hold (World Bank Report, 2014). Farms have also been abandoned by farmers, and where farming operations are ongoing, there is shortage of labor due to quarantine and migration of families. These have affected production and marketing of food stuffs like rice. A recent report from the United Nations showed that food prices have increased by $150 \%$.

In Sierra Leone, agriculture is the mainstay of the vast majority of the population and accounted for 50percent of the economy in 2013. (World Bank Report, 2014). The two eastern districts -Kailahun and Kenema the major areas affected by the virus make up one fifth of the country's population, and contain the most productive agricultural areas in Sierra Leone, producing both the staple food-rice and cash crops-cocoa and palm oil, they also produce about 18percent of the total domestic rice output (World Bank Report, 2014). With the movement restrictions and quarantine measures in place, production is expected to be disrupted, leading to a hike in prices in of foods. According to a World Bank report September, 17th 2014, rice prices have spiked up to 30 percent in these affected areas. In Guinea, the virus has led to mass exodus of people which has affected key export commodities such as cocoa and palm oil. Coffee production has also fallen by half (from 5, 736 tons to 2, 671 tons) cocoa production has declined by a third from (3,511 tons to 2,296 tons ) palm oil production has also fallen by $75 \%$ (World Bank Report, 2014). Similarly, in Bangkok Thailand exporters in the country say they are currently unable to ship much of their rice produce to African ports because individuals are unwilling to man the vessels due to the fear of contracting the Ebola virus. This has negatively affected the income of farmers in the country.

A major consequence of the Ebola virus from the above scenarios in the 3 countries is reduction in production activities. Reduced outputs of food and cash crops in these countries will affect the volumes of exports resulting in lower profits for the producers and sellers leading to a fall in household expenditures. The 
importing countries will also be affected because a short fall in export supplies will lead to hike in price of food and cash crops coming into the country. These conditions will culminate into a reduction in economic growth. Below is table that describes the initial and revised projection of agriculture contribution to GDP in Liberia, Sierra Leone and Guinea.

Table 3: Liberia, Sierra Leone, and Guinea - Estimated GDP impact of Ebola (2014)

\begin{tabular}{|l|l|l|l|}
\hline Countries & Contribution to growth (\%) & Initial projection(June 2014) & Revised Projection \\
\hline Sierra Leone & 27.8 & 4.8 & 2.6 \\
\hline Liberia & 18.0 & 3.5 & 1.3 \\
\hline Guinea & 20.3 & 5.7 & 3.3 \\
\hline
\end{tabular}

Source: World Bank

From the table above agricultural contribution to GDP was initially projected at 4.8 percent in Sierra Leone, 3.5 percent in Liberia and 5.7 percent before the Ebola virus outbreak but these figures have slumped due to the virus outbreak. This negative change can be attributed to disruptions in agricultural production due to movement restrictions which have caused the volumes of exports and imports to fall.

\subsection{Impact on Mining Sector:}

The mining sector accounts for about 17 percent of GDP and 56 percent of the US\$559million worth of total exports in 2013. (World Bank Report, 2014). Production and exports are dominated by two large iron ore mining companies, ArcelorMittal and China Union. Production is still ongoing at the largest mining company (Arcelor Mittal) with production of approximately 3.3million tons up to August, to achieve planned production of 5.2million by the end of 2014. However, a planned investment to expand capacity to 15 million has been put on hold. China Union which had projected production of approximately 2.4 million for 2014 has closed its operations. Movement restrictions have curtailed artisanal mining of gold and diamond.(World Bank Report, 2014)

In Sierra Leone, mining accounts for 87 percent of industry, this makes up about 20 percent of the economy. Mining is dominated by the iron ore sector which accounts for 16 percent of GDP. According to the World Bank report September $17^{\text {th }} 2014$, the Ebola virus has had little effect on mining production in the state and companies have indicated interest to continue production. Nevertheless, many of these companies are operating with reduced expatriates and there is a likelihood of disruption. If this disruption occurs it will have an adverse effect on exports and government revenue. In Guinea, mining industry has not been severely affected because the main mines are not located in the affected areas. Where production was forecast to 3.0 percent before Ebola project outputted has been revised downward to only 3.4 percent. (World Bank Report, 2014)

From the above mentioned conditions a negative impact on mining production will lead to a fall in the volume of exports and imports which develops a ripple effect on profits, income and expenditure, resulting in a negative economic growth.

Below is a table that shows the Initial and revised contribution of mining to GDP in Sierra Leone, Liberia and Guinea.

Table 4: Liberia, Sierra Leone, and Guinea-Estimated GDP impact of Ebola (2014)

\begin{tabular}{|l|l|l|l|}
\hline Countries & Contribution to growth (\%) & Initial projection (Jan 2014) & Revised projection \\
\hline Sierra Leone & 39.6 & 27.3 & 21.8 \\
\hline Liberia & 27.3 & 4.4 & -1.3 \\
\hline Guinea. & 3.8 & -3.0 & -3.4 \\
\hline
\end{tabular}

Source: World Bank

From the table above, initial projected contribution of mining sector to GDP was 27.3, 4.4, and -3.0 percent in 2014 before the Ebola virus, but due to the virus outbreak these projection has fallen in these countries. This occurrence in the mining industry is due to evacuation of personnel in the industry, shutdown of companies and reduction in demand.

\subsection{Impact on other Sectors:}

Ebola will also affect the economy through other areas. Namely; Health, Transport, Tourism, education and hospitality. Ebola will affect the health sector for the following reasons: 1) it will increase the number of people seeking health care services 2) The cost will increase especially in private hospitals. Government will then face tradeoffs; Spending for health care services versus spending for other objectives'.

Transport: As a result of movement restrictions across borders and into major cities, transport workers could have lower returns from low passenger turnout. Workers in local and international airlines' may be relieved of their jobs due to flight ban to certain countries. For example British and emirate airlines have stopped flights to Sierra Leone and Liberia. In Senegal planes carrying humanitarian aid have been prevented 
from landing in the country, In Liberia, petrol and diesel prices are down by 21 and 35 percent, regulations limiting taxis to 4 passengers have raised the cost of domestic travels, the cost of transporting goods has closed increased in some places by $50 \%$. Flights in Liberia have dropped from 27 weekly flights up to August to 6 at the beginning of September. (World Bank, 2014). Tourist will be unable to travel to their various holiday destinations' due to ban on flight movements to certain countries. This will result in lower profits for the tourism industry. Hotels are not left out, because of air travels bans, foreign companies evacuating their staffs, cancellation of conferences and seminars could lead to patrons being sparse at the hotel venues. In Liberia, Average hotel occupancy has dropped from $70 \%$ before the crisis to about $30 \%$ now. (World Bank, 2014)

\section{Fiscal Impacts:}

From the above analysis on the effect of Ebola virus on major industries and other sectors of the economy, one can expect government revenue generation to decrease and expenditure to increase due to lower profits, lesser incomes, increased health care and infrastructural spending. A recent World Bank report September $17^{\text {th }}$ has made estimations on the revenue and expenditure figures due to the virus outbreak. Below is a table that shows the fiscal impact of Ebola.

Table 5: Liberia, Sierra Leone, and Guinea -Estimated Fiscal impact of Ebola (revenue) (US millions)

\begin{tabular}{|l|l|l|}
\hline Countries & Original projection of revenue. & Revised projection of revenue. \\
\hline Sierra Leone & 745 & 688 \\
\hline Liberia & 558.9 & 513.2 \\
\hline Guinea & 1,701 & 1,650 \\
\hline
\end{tabular}

Source: World Bank

Table6: Liberia, Sierra Leone, and Guinea- Estimated Fiscal impact of Ebola (expenditure) (US millions)

\begin{tabular}{|l|l|l|}
\hline Countries & Original projection of revenue & Revised projection of revenue. \\
\hline Sierra Leone & 938 & 960 \\
\hline Liberia & 717.6 & 764.7 \\
\hline Guinea & 2,046 & 3,080 \\
\hline
\end{tabular}

Source: World Bank

From the above tables, comparing the fiscal projections (Revenue and expenditure) it can then be said that the fiscal impact of Ebola will have a negative effect on the economic growth of West African economies (Liberia, Sierra Leone, and Guinea.)

In other to illustrate the impact of the Ebola virus below is a simple process that shows the relationship between the Ebola virus and economic growth in West Africa.

Figure 2: Relationship between Ebola virus and Economic growth

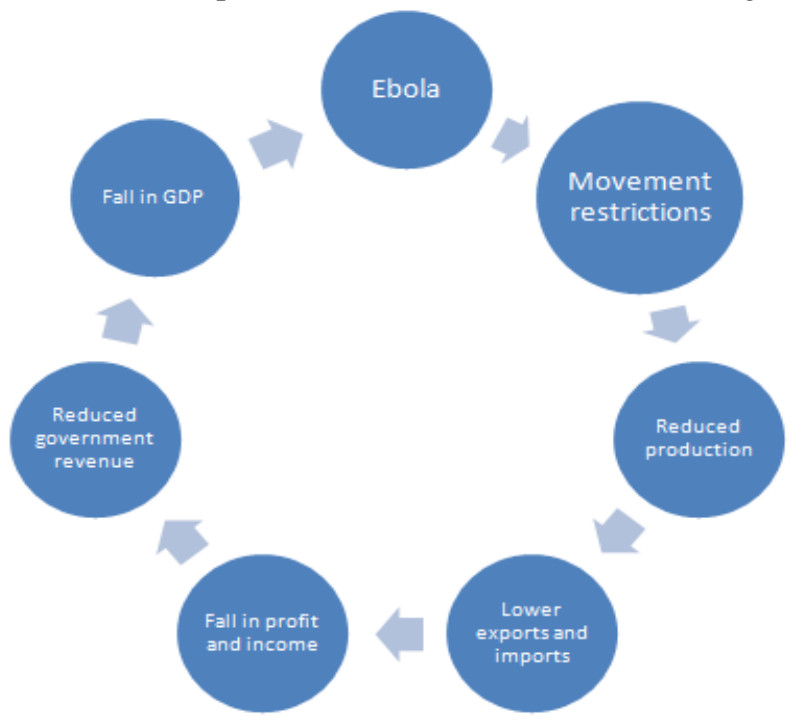

From the above chart, the Ebola virus has resulted in movement restrictions, leading to reduced production, this inturn has lowered the volume of exports and imports developing into lower profits and incomes, reducing government revenue and increasing expenditure on health care and infrastructure culminating into a fall in Gross Domestic product (GDP)

Although the virus attack is no good news for African Economies, but it will change the negative habits of African towards their environment. Many African countries have huge water and sanitation challenges 
despite effort by developments banks like the African Development Bank and World Bank to reverse the situation. It is normal to see a chain of Africans urinating on the streets, many homes located in slumps do not have toilets, Human and material waste are being disposed in ways that are far from pleasant, when indviduals build houses they hardly factor in hygiene and the environment. It is believed that the Ebola virus will help change this kind of behaviours and make the continent a better palce to inhabit.

\section{Conclusively}

The African continent has been faced with various health challenges, but the Ebola virus is another deadly attack that has caused loss of lives, the impact of the virus on West African Economies in the short term is still minimal, but if the virus persists the impact of the disease on the economies in the long term could be very devastating. According to a recent World Bank report September $17^{\text {th }}$, if Ebola is contained within the next six to nine months and activities gradually increase across most sectors (Low Ebola), the Liberian economy could post a modest rebound in 2015, with GDP growth of 2.6 percent: that would roughly amount to US\$82miilion, in lost GDP, under a slow containment scenario. The sharp contraction in agriculture, manufacturing and services would lead to an overall GDP contraction of nearly 5 percent and a loss of US\$228million in output. In Sierra Leone under the assumption the virus is contained quickly, non iron ore GDP will rise by 4.5 percent in 2015 and overall GDP rises by 7.7 percent relative to 8.9 percent in the precrisis projection. A slow containment scenario will lead to US\$439miilion in lost GDP more than 7times the loss in low Ebola case. In Guinea, high containment will result in growth of GDP from 2.0 percent to 5.0 percent, but slow containment; will result in a loss of US\$142million. For the 3 countries, the fortified GDP in 2015 sums to US\$97million in the low Ebola case and a striking US\$809 million in the high Ebola case.

In a nutshell the impact of the virus on West African Economies will be more devastating in the long term if the virus is not highly contained in the short terms. Therefore, it is essential that governments and international bodies cooperate to ensure the impact of virus is mitigated in the short term to avert economic consequences in the future. The African Development Bank, United States Government and Nigerian government should be commended for their efforts in curtailing the virus. However, more contributions are needed from other governments and international bodies to put an end to this deadly virus.

\section{References}

[1]. Alemu Z, Roe T, and Smith R, 2005, “Impact of HIV on Total Factor Productivity”, Bulletin Number 05-02

[2]. Arndt C. and J.D. Lewis (2000). "The Macro Implications of HIV/AIDS in South Africa: A Preliminary Assessment," South African Journal of Economics, 68(5): 856-87.

[3]. Arndt, C., And J.D. Lewis (2001) “The HIV/ AIDS pandemic in South Africa: Sectoral Impacts and Unemployment", Journal of International Development, 13:427-449

[4]. Badiane O. (1991): “Regional Agricultural Markets and Development Strategies in West Africa”, Quarterly Journal of International Agriculture vol 30, No 1

[5]. Biekpe N and Gossel S. (2013): "Economic growth, trade and capital flows: A causal analysis of post liberalized South Africa", Journal of International Trade and Economic Development, vol 23, No. 6, 815-836.

[6]. Bloom, David E, David Canning, and Bryan Graham, 2003, "Longevity and Life cycle Savings", Scandinavian Journal of Economics, Vol. 105 (September), pp-319-38.

[7]. Bloom, David E, David Canning, and Pia Malaney, 2000, "Demographic Change and Economic Growth in Asia”, Supplement to Population and Development Review, vol.26, pp 257-90.

[8]. Jamison D, Bloom E, and Canning D. 2004:"Health, Wealth and Welfare".

[9]. Oliver m and Charles A. (2005) : "Trade policy performance in Sub Saharan Africa since the 1980s", Credit Research paper, No. $05 / 13$

[10]. Over, A.M. (1992). “ The Macroeconomic Impact of AIDS in Sub-Saharan Africa”, AFTPN Technical working paper 3, Population, Health and Nutrition Division, African Technical Department, Washington Dc, World Bank.

[11]. Sachs D, and Gallup L. "The Economic Burden of Malaria” American Journal of Tropical Med. Hyg, vol 64 pp85-96.

[12]. Sackey J. and T. Raparla (2000). Lesotho: The Development Impact of HIV/AIDS. Selected issues and options, AFTMI Report No. 21103- Lso, Macroeconomic Technical Group, African Region Washington, DC, World Bank.

[13]. Uexkull V. (2012). "Regional Trade and Employment in ECOWAS" Employment working paper No. 114. International Labor Organization

[14]. Warner M, and Sachs D. (1996): "Sources of Slow growth in African economies" Journal of African economies, vol 6, No 3, pp. 335-76 